\title{
Current Antiviral Therapy for Chronic Hepatitis B
}

\begin{abstract}
During the past decade, major breakthroughs have been achieved in treatment of chronic hepatitis B. Currently, three therapeutic agents are approved for chronic hepatitis $\mathrm{B}$ : interferon-alpha, lamivudine and adefovir dipivoxil. In patients with $\mathrm{HBeAg}$ positive chronic hepatitis B, all of these drugs achieve HBeAg loss (24-33\%) and anti-HBe seroconversion (12-30\%) rates that are superior to those observed in untreated controls. Interferon-alpha has several drawbacks, such as the parenteral administration and the development of frequent and potentially serious side effects. Lamivudine is a safe drug with rare and generally mild side effects. Lamivudine induces an initial virological remission in $70-90 \%$ of patients, but only $30-40 \%$ of patients remain in remission after the third year due to progressively increasing viral resistance. The main advantage of adefovir dipivoxil is the rare emergence of resistance, which has been identified in less than $2 \%$ of patients at $2 \mathrm{yr}$ of treatment. Adefovir is also effective against lamivudine-resistant strains. This review will focus on the natural history and recently gained knowledge on the treatment of chronic hepatitis B.
\end{abstract}

Key Words : Hepatitis B; Hepatitis B Virus; Interferon-alpha; Lamivudine; Adefovir Dipivoxil; Antiviral Agents
Young-Suk Lim, Dong Jin Suh

Department of Internal Medicine, University of Ulsan College of Medicine, Asan Medical Center, Seoul, Korea

Received: 23 June 2004

Accepted: 13 July 2004

\section{Address for correspondence}

Dong Jin Suh, M.D.

Department of Internal Medicine, University of Ulsan College of Medicine, Asan Medical Center, 388-1 Poongnap-dong, Sonpa-gu, Seoul 138-736, Korea Tel : +82.2-3010-3191, Fax : +82.2-476-0824 E-mail : djsuh@amc.seoul.kr

\section{INTRODUCTION}

Chronic hepatitis B virus (HBV) infection is a major public health problem and leading cause of chronic liver disease and hepatocellular carcinoma (HCC) in Korea. In the past 10 $\mathrm{yr}$, remarkable strides have been made in the antiviral therapy of HBV infection. However, due to many limitations in the current treatments, careful considerations of the patient's age, severity of liver disease, likelihood of response, and potential side effects are needed before treatment is initiated. The choice of therapy is dependent on a balance between longterm benefit versus risk, as well as cost and patient preference. The decision to treat or not to treat and with what kind of treatment should be made jointly by the physician and patient after careful consideration of all the factors listed above. This review will focus on the current antiviral treatment of patients with HBV related compensated chronic liver diseases.

Currently, consensus guidelines regarding the antiviral therapy for hepatitis B is not available in Korea. Therefore, the Practice Guidelines of the American Association for the Study of the Liver Diseases (AASLD), International Consensus Conference of European Association for the Study of the Liver (EASL), and Asia-Pacific Association for the Study of Liver (APASL) guidelines on hepatitis B are referred for the recommendations in this review (1-5).

\section{NATURAL COURSE OF CHRONIC HEPATITIS B VIRUS INFECTION}

Despite significant progresses in the prevention of HBV transmission, there are more than 300 million chronic HBV carriers worldwide, and three fourths of such carriers are living in Asia, including Korea. The prevalence of chronic HBV carriers are still about $4.4 \%$ in Korea (6-9). Although the natural history of chronic HBV infection is variable, $15 \%$ to $40 \%$ of such carriers will develop serious sequelae such as cirrhosis, hepatic decompensation, and HCC during their lifetime $(1,4)$.

The natural history of chronic hepatitis B is largely determined by the persistence of viral replication and the vigor of the host immune response to infected hepatocytes. In general, progression to chronic hepatitis B after acute infection is influenced by the age of acquisition of infection and the degree of immunologic competence. In endemic areas of HBV infection, the most common mode of HBV infection is perinatal transmission, which result in high rate of chronicity over $90 \%$. The natural course of perinatally acquired HBV infection may be divided into several phases $(10,11)$. The first phase is characterized by the presence of hepatitis $\mathrm{B}$ e antigen $(\mathrm{HBeAg})$ and high levels of serum HBV DNA but normal aminotransferases (ALT). This immune-tolerant phase is most commonly seen in children and adolescents, and typi- 
cally lasts $10-30 \mathrm{yr}$, during which time there is a very low rate of spontaneous $\mathrm{HBeAg}$ clearance. The second phase is immune-clearance phase which is characterized by the elevation of serum ALT as well as the presence of HBeAg and high levels of serum HBV DNA (HBeAg positive chronic hepatitis). During this phase, which typically occurs during second to fourth decade of chronic infection, spontaneous $\mathrm{HBeAg}$ clearance occurs at an annual rate of about $10 \%$. The third phase is characterized by the clearance of $\mathrm{HBeAg}$, development of antibody to HBeAg (anti-HBe), low or sometimes undetectable serum HBV DNA and normal ALT levels. This inactive carrier state may persist indefinitely or be interrupted by reactivation of $\mathrm{HBV}$ replication. $\mathrm{HBeAg}$-negative carriers are a heterogeneous group. Most of them have low levels of viral DNA, relatively normal levels of ALT, and a good prognosis. However, at least 15 to $20 \%$ of such carriers have elevated levels of ALT and viral DNA in the blood (HBeAg negative chronic hepatitis). Patients in this phase are older, have been infected for longer duration of time, and have more advanced liver disease. The virus in many such HBeAg-negative chronic hepatitis B patients harbors mutations in the preC or core promoter region that prevent the production of HBeAg (12).

\section{TREATMENT OF CHRONIC HEPATITIS B}

The aims of treatment of chronic hepatitis B are to achieve sustained suppression of HBV replication and to stop the progression of hepatic inflammation. The usual marker of successful therapy in $\mathrm{HBeAg}$-positive chronic hepatitis B is the "HBeAg Seroconversion", which includes all of followings: normalization of serum ALT level, undetectable serum HBV DNA by an unamplified assay $\left(<10^{5}\right.$ copies $\left./ \mathrm{mL}\right)$, the loss of $\mathrm{HBeAg}$, and seroconversion to anti-HBe. True cure of infection (loss of HBsAg and complete disappearance of viremia, as measured by stringent PCR assays) is achieved only infrequently (in 1 to $5 \%$ of patients) with current regimens although the increasing numbers of active antiviral drugs might lead to an upward revision of this figure in the future. In the case of patients with $\mathrm{HBeAg}$-negative chronic hepatitis, sustained normalization of ALT and undetectable HBV DNA by PCR assay were suggested as end point of treatment $(2,13,14)$.

Currently, three therapeutic agents, interferon (IFN) and two orally administered antiviral agents lamivudine and adefovir dipivoxil, have been approved by the FDA for the treatment of chronic hepatitis B (Table 1). These antiviral treatments are recommended only for the patients with positive HBV-DNA by non-amplified assay and elevated ALT levels of at least more than twice the upper normal limit, as patients with normal ALT levels respond poorly to these agents. For patients with higher ALT levels of more than five times the upper normal limits, close monitoring is recommended as
Table 1. Comparison of three approved treatment of chronic hepatitis $B$

\begin{tabular}{|c|c|c|c|}
\hline & IFN & Lamivudine & Adefovir \\
\hline \multicolumn{4}{|l|}{ Indications } \\
\hline HBeAg+normal ALT & - & - & - \\
\hline HBeAg+chronic hepatitis & + & + & + \\
\hline HBeAg-chronic hepatitis & + & + & + \\
\hline Decompensated cirrhosis & - & + & + \\
\hline \multicolumn{4}{|l|}{ Duration of treatment } \\
\hline $\mathrm{HBeAg}+$ chronic hepatitis & 4-6 months & $>1 \mathrm{yr}$ & $>1 \mathrm{yr}$ \\
\hline HBeAg-chronic hepatitis & $1 \mathrm{yr}$ & $\gg 1 \mathrm{yr}$ & $\gg 1 \mathrm{yr}$ \\
\hline Decompensated cirrhosis & NA & Indefinite & Indefinite \\
\hline \multicolumn{4}{|l|}{ Durability of response } \\
\hline HBeAg+chronic hepatitis & $80-90 \%$ & $50-80 \%$ & Unknown \\
\hline HBeAg-chronic hepatitis* & $20-25 \%$ & $\sim 10 \%$ & Unknown \\
\hline Route & Subcutaneous & Oral & Oral \\
\hline Side effects & Many & Negligible & $\begin{array}{c}\text { Potential } \\
\text { nephrotoxicity }\end{array}$ \\
\hline Contraindications & ++ & - & - \\
\hline Drug resistance & & $\begin{array}{l}\sim 20 \% / 1 \mathrm{yr} \\
\sim 70 \% / 5 \mathrm{yr}\end{array}$ & $2 \% / 2 \mathrm{yr}$ \\
\hline Cost (Korean Won) & $\begin{array}{c}3,000,000 \\
(6 \mathrm{mo})\end{array}$ & $\begin{array}{c}1,400,000 \\
(1 \mathrm{yr})\end{array}$ & $\begin{array}{c}5,400,000 \\
(1 \mathrm{yr})\end{array}$ \\
\hline
\end{tabular}

*After 12 months of treatment. NA, Not analysed.

these patients may be in a disease exacerbation stage leading to severe hepatitis or hepatic decompensation.

\section{INTERFERON}

For many years, administration of IFN-alfa ( 5 million units everyday or 10 million units three times per week subcutaneously, for at least four months) was the mainstay of therapy. About $30 \%$ of patients who tolerated this regimen had a successful response, defined as a loss of $\mathrm{HBeAg}$, the development of anti-HBe, and a decline in serum alanine aminotransferase levels, compared with $12 \%$ of controls (15).

However, the side effects of IFN-alfa (fever, myalgias, thrombocytopenia, and depression) are troublesome for many patients. Moreover, a flare of liver injury occurs in many patients during administration of IFN-alfa, often just before or during clearance of $\mathrm{HBeAg}$. This phenomenon may reflect the immuno-modulatory activity of IFN-alfa, which, in addition to impairing HBV replication, can also cause up-regulation of MHC class I antigens on hepatocytes and thereby augment the recognition of infected cells by cytotoxic $\mathrm{T}$ lymphocytes. These flares are intrinsic to the therapy and, as markers of enhanced antiviral immune responsiveness, often presage a successful outcome. Treatment with IFN-alfa is generally contraindicated in very advanced liver disease, since in such cases the flares may precipitate overt liver failure despite dose reduction (16). Moreover, patients with advanced cirrhosis and splenomegaly usually have base-line leukopenia and thrombocytopenia, which can get worse by IFN treatment. 
Controversy still exists over Asian patients who usually acquire $\mathrm{HBV}$ infection at birth. These patients are presumably immunologically tolerant of hepatitis B infection and have minimal elevation of ALT values. However, even in Asian patients, when their ALT is elevated, the response rate to IFN is comparable to that of Western patients (17). Sustained loss of HBV replication markers is unlikely in patients with chronic hepatitis B infected with precore mutants when treated with IFN for 6 months. However, longer courses of IFN-alpha were reported to improve the sustained response rates, reaching $20-25 \%(18,19)$.

IFN-alfa-induced $\mathrm{HBeAg}$ clearance has been reported to be durable in $80 \%$ to $90 \%$ of patients during a follow-up period of 4 to $8 \mathrm{yr}$ after discontinuation of therapy. However, particularly in Asian patients, complete eradication of HBV is rare as most responders continued to have detectable HBVDNA in serum using sensitive PCR assays unless they became HBsAg-negative.

The therapeutic effect of new pegylated IFN for chronic hepatitis B remains to be studied.

\section{LAMIVUDINE}

Lamivudine, the (-) enantiomer of $2^{\prime}$-deoxy- 3 '-thiacytidine, is a cytosine analog with potent inhibitory effect on the RNA-dependent DNA polymerase of HBV and HIV. Lamivudine is rapidly absorbed orally with a bioavailability of more than $80 \%$, and it is excreted in urine. It is a safe drug with rare and generally mild side effects $(20,21)$. In general, treatment with lamivudine results in a reduction of 3 to $4 \log$ in circulating levels of HBV DNA in the first three months of therapy; this decline is associated with more rapid loss of $\mathrm{HBeAg}$, seroconversion to anti-HBe-positive status, and improvement in serum aminotransferase levels. The drug is usually well tolerated, a factor that has led to the rapid displacement of IFN alfa from the list of first-line therapies for HBV. Lamivudine is not immunomodulatory and can be used in patients with decompensated cirrhosis (22).

Although lamivudine is not an immunomodulator, there is strong evidence that successful treatment with lamivudine relies to some extent on an adequate host immune response. This evidence emerged from a retrospective examination of subgroups of patients with optimal responses to therapy, which revealed a strong correlation between $\mathrm{HBeAg}$ clearance and elevated pretreatment values for alanine aminotransferase. $\mathrm{HBeAg}$ seroconversion occurred in $2 \%, 7 \%, 20 \%$, and $42 \%$ of patients with pretreatment ALT levels within normal, 1-2 times , 2-5 times, and more than 5 times of the upper limit of normal range, respectively (23). This finding suggests that by reducing the viral load, lamivudine allows the immune and inflammatory responses to deal more effectively with the remaining infected hepatocytes in the host. Among Asian patients with elevated ALT levels, HBeAg seroconversion rates are similar to those in Western patients with comparable ALT levels (23). Histological improvement defined as a reduction in necroinflammatory score greater than or equal to 2 points was observed in $49 \%$ to $56 \%$ of treated patients and in $23 \%$ to $25 \%$ of controls.

Reductions of HBV-DNA serum levels were noted after 2 weeks of lamivudine therapy in $97 \%$ of treated patients and eventually became undetectable in almost all patients. However, after premature cessation of the therapy, serum HBV-DNA in these patients almost always reappeared (24). This phenomenon has been attributed to the persistence of covalently closed circular DNA (cccDNA) of HBV in the nuclei of hepatocytes, which results in rapid return of HBV replication after lamivudine withdrawal. Follow-up reports of the multicenter Asian study showed that HBeAg seroconversion rates increased with the duration of treatment from $17 \%$ at $1 \mathrm{yr}$ to $27 \%, 33 \%, 47 \%$, and $50 \%$ at $2,3,4$, and 5 yr, respectively $(24,25)$.

The principal limitation of lamivudine therapy is the development of drug resistance, which is mediated largely by point mutations at the YMDD motif at the catalytic center of the viral reverse transcriptase (26). The resulting mutants are slightly less fit than wild-type HBV in the absence of the drug, but they are strongly selected in its presence. By the end of one year of therapy, 15 to $20 \%$ of patients have resistant variants in the circulation; the figure rises to $40 \%$ by two years, and to $67 \%$ by the fourth year $(24,25)$.

The clinical significance of the development of resistance is still being debated. Clearly, in many patients, resistance presages a return of higher-level viremia, and in some of these patients further liver injury develops $(27,28)$. However, although the level of viremia rises, in many patients it may still remain below pretreatment levels, perhaps as a result of the reduced fitness of the variants (29). In addition, some patients continue to undergo conversion from HBeAg-positive status to $\mathrm{HBeAg}$-negative status, even after the appearance of lamivudine-resistant mutants $(24,28)$. Therefore, some experts favor the continuation of lamivudine therapy in compensated patients with resistant variants, especially since transient exacerbations of liver injury may develop in some patients when antiviral therapy is withdrawn. However, fatal severe flare may also develop during the continuation of lamivudine therapy. Recently, it was reported that there is no benefit in continued lamivudine therapy and it is generally safe to stop lamivudine in patients harboring YMDD mutants $(30,31)$. Now that newer anti-HBV drugs are available, additional options exist for the patients with resistant strains of HBV. In patients with lamivudine resistant decompensated liver cirrhosis, adefovir can be used as a rescue therapy.

Another drawback of lamivudine therapy is the low durability of long-term response in patients who achieve $\mathrm{HBeAg}$ seroconversion. Although $\mathrm{HBeAg}$ seroconversion after stopping lamivudine therapy has been reported to be maintained in $77 \%$ of patients from Western countries, such long-term 
responses appear to be less durable in Korean patients (32-34). In one of our studies, the cumulative post-treatment relapse rates at 1 and $2 \mathrm{yr}$ were as high as 38\% and 49\% (33). The percentage of responders who maintain $\mathrm{HBeAg}$ seroconversion after cessation of lamivudine appears to be associated with the duration of additional lamivudine therapy after the seroconversion, serum HBV levels at the time of cessation of therapy and perhaps with the duration of $\mathrm{HBV}$ infection (33-36). Although the duration of extension of lamivudine therapy after HBeAg seroconversion is not determined yet, international guidelines recommend to continue therapy for 3-6 months after seroconversion to maintain durability (1-4).

\section{ADEFOVIR DIPIVOXIL}

Adefovir dipivoxil is the second nucleoside analogue, which has been recently approved for use in chronic hepatitis B. Adefovir dipivoxil is the oral prodrug of an acyclic monophosphate adenine analog, which is a selective inhibitor of DNA polymerase and reverse transcriptase activity of HBV. Large, placebo-controlled clinical trials have shown potent activity of adefovir against $\mathrm{HBV}$ with significant biochemical, virologic, and histologic improvement in chronic hepatitis $\mathrm{B}$ patients $(37,38)$. In HBeAg-positive chronic hepatitis B, a 12-month course of adefovir dipivoxil, at a daily dose of 10 $\mathrm{mg}$, was found to achieve a loss of $\mathrm{HBeAg}$ in $24 \%$ of patients, compared with $11 \%$ of controls, and the rate of HBeAg seroconversion (12\%) was significantly greater than that observed in the placebo group (6\%) (37). In patients receiving adefovir, HBV DNA was reduced by 3 to $4 \log$ from baseline, and there was histologic improvement in the liver. Although clinical trials which directly compare the antiviral effect of adefovir with lamivudine have not been performed, the rate of $\mathrm{HBeAg}$ seroconversion among patients who received 10 $\mathrm{mg}$ dose of adefovir $(12 \%)$ in phase III trial was similar to that reported in randomized trials using lamivudine $100 \mathrm{mg}$ $(16 \%)(20,21)$. Similar to previous observations in patients treated with IFN-alfa or lamivudine, higher baseline alanine aminotransferase levels were associated with an improved efficacy of adefovir dipivoxil therapy. Similar efficacy was documented in HBeAg-negative patients with abnormal liver function and elevated levels of viral DNA (38). Moreover, the drug effectively inhibits the replication of lamivudine-resistant HBV mutants. In patients with compensated or decompensated chronic hepatitis $B$ who have lamivudine resistance, HBV DNA suppression and ALT normalization were achieved in similar proportions of patients who received adefovir alone or combination of adefovir and lamivudine (39-41).

The main advantage of adefovir dipivoxil is the rare emergence of resistance, which makes the drug a favorable candidate for long-term maintenance therapy for patients with advanced HBV liver disease. A new adefovir-resistant mutant, rtN236T, has been identified in only $1.6 \%$ of patients at 96 weeks' follow-up (42).

On the other hand, its main disadvantages are its high cost and the absence of very long-term data on its efficacy and safety. Long-term effect of adefovir dipivoxil in patients with HBeAg-negative chronic hepatitis B also remains to be elucidated.

Adefovir is well tolerated and has similar side effect profile as placebo in phase III clinical trials. However, adefovir, when used in high doses, has been reported to be associated with renal tubular dysfunction resembling Fanconi syndrome as well as deterioration in renal function (43). Because of these concerns, only the $10 \mathrm{mg}$ daily dose has been approved. At this dose, none of the patients in the two Phase III trials developed renal tubular dysfunction or nephrotoxicity after 48 week of treatment $(37,38)$. However, renal function must be monitored closely in all patients. More frequent monitoring should be performed in patients on adefovir for more than 1-yr and with pre-existing renal insufficiency. Dosing interval adjustments are recommended for patients with a creatinine clearance less than $50 \mathrm{~mL} / \mathrm{min}$ and in those requiring haemodialysis.

\section{CONCLUSIONS AND RECOMMENDATIONS}

Current therapy of chronic hepatitis B has limited longterm efficacy. Thus, careful consideration of severity of liver disease, likelihood of response, and potential adverse events and complications as well as costs is needed before treatment is initiated. The advantages of IFN include a finite duration of treatment, a more durable response and the lack of resistant mutants. The disadvantages of IFN are the costs and side effects. Lamivudine is well tolerated but the durability of response appears to be lower, and long-term therapy is associated with increasing risk of drug-resistant mutants which may negate the initial benefits and in some patients result in worsening of liver disease. The main advantages of adefovir include its activity against lamivudine-resistant mutants and a very low rate of resistance during initial therapy. However, adefovir is significantly more costly than lamivudine, and the durability of response, long-term safety and risk of drug resistance remain to be determined. In the future, as newer drugs are coming, combination therapies with multiple antiviral drugs which would provide better long-term suppressive effect for $\mathrm{HBV}$ and less drug resistance are anticipated.

\section{REFERENCES}

1. Lok AS, McMahon BJ. Chronic hepatitis B. Hepatology 2001; 34 : 1225-41.

2. Lok AS, McMahon BJ. Chronic hepatitis B: update of recommendations. Hepatology 2004; 39: 857-61.

3. EASL Jury. EASL international consensus conference on hepatitis 


\section{B. J Hepatol 2003; 38: 533-40.}

4. Core working party for Asia-Pacific consensus on hepatitis B and C. Consensus statements on the prevention and management of hepatitis $B$ and hepatitis $C$ in the Asia-Pacific region. J Gastroenterol Hepatol 2000; 15: 825-41.

5. Liaw YF, Leung N, Guan R, Lau GK, Merican I. Asian-Pacific consensus statement on the management of chronic hepatitis B: An update. J Gastroenterol Hepatol 2003; 18: 239-45.

6. Lee WM. Hepatitis B virus infection. N Engl J Med 1997; 337: 173345.

7. Maddrey WC. Hepatitis B: an important public health issue. J Med Virol 2000; 61: 362-6.

8. Jang MK, Lee JY, Lee JH, Kim YB, Kim HY, Lee MS, Park CK, Yoo JY. Seroepidemiology of HBV infection in South Korea, 1995 through 1999. Korean J Intern Med 2001; 16: 153-9.

9. Lee DH, Kim JH, Nam JJ, Kim HR, Shin HR. Epidemiological findings of hepatitis B infection based on 1998 National Health and Nutrition Survey in Korea. J Korean Med Sci 2002; 17: 457-62.

10. Chang MH. Natural history of hepatitis B virus infection in children. J Gastroenterol Hepatol 2000; 15 (Suppl): E16-9.

11. Bortolotti F, Cadrobbi P, Crivellaro C, Guido M, Rugge M, Noventa F, Calzia R, Realdi G. Long-term outcome of chronic type B hepatitis in patients who acquire hepatitis $B$ virus infection in childhood. Gastroenterology 1990; 99: 805-10.

12. Hadziyannis SJ, Vassilopoulos D. Hepatitis $B$ e antigen-negative chronic hepatitis B. Hepatology 2001; 34: 617-24.

13. Papatheodoridis GV, Hadziyannis SJ. Diagnosis and management of pre-core mutant chronic hepatitis B. J Viral Hepat 2001; 8: 311-21.

14. Hadziyannis SJ, Papatheodoridis GV, Vassilopoulos D. Treatment of HBeAg-negative chronic hepatitis B. Semin Liver Dis 2003; 23: 81-8.

15. Wong DK, Cheung AM, O'Rourke K, Naylor CD, Detsky AS, Heathcote J. Effect of alpha-interferon treatment in patients with hepatitis $B$ e antigen-positive chronic hepatitis B. A meta-analysis. Ann Intern Med 1993; 119: 312-23.

16. Perrillo R, Tamburro C, Regenstein F, Balart L, Bodenheimer H, Silva M, Schiff E, Bodicky C, Miller B, Denham C. Low-dose, titratable interferon alfa in decompensated liver disease caused by chronic infection with hepatitis B virus. Gastroenterology 1995; 109: 908-16.

17. Guan R. Interferon monotherapy in chronic hepatitis B. J Gastroenterol Hepatol 2000; 15 (Suppl): E34-40.

18. Manesis EK, Hadziyannis SJ. Interferon alpha treatment and retreatment of hepatitis B e antigen-negative chronic hepatitis B. Gastroenterology 2001; 121: 101-9.

19. Lampertico P, Del Ninno E, Vigano M, Romeo R, Donato MF, Sablon E, Morabito A, Colombo M. Long-term suppression of hepatitis $B e$ antigen-negative chronic hepatitis $B$ by 24-month interferon therapy. Hepatology 2003; 37: 756-63.

20. Dienstag JL, Schiff ER, Wright TL, Perrillo RP, Hann HW, Goodman Z, Crowther L, Condreay LD, Woessner M, Rubin M, Brown NA. Lamivudine as initial treatment for chronic hepatitis $B$ in the United States. N Engl J Med 1999; 341: 1256-63.

21. Lai CL, Chien RN, Leung NW, Chang TT, Guan R, Tai DI, Ng KY, Wu PC, Dent JC, Barber J, Stephenson SL, Gray DF. A one-year trial of lamivudine for chronic hepatitis B. Asia Hepatitis Lamivudine Study Group. N Engl J Med 1998; 339: 61-8.

22. Villeneuve JP, Condreay LD, Willems B, Pomier-Layrargues G, Fenyves D, Bilodeau M, Leduc R, Peltekian K, Wong F, Margulies $\mathrm{M}$, Heathcote EJ. Lamivudine treatment for decompensated cirrhosis resulting from chronic hepatitis B. Hepatology 2000; 31: 207-10.

23. Perrillo RP, Lai CL, Liaw YF, Dienstag JL, Schiff ER, Schalm SW, Heathcote EJ, Brown NA, Atkins M, Woessner M, Gardner SD. Predictors of HBeAg loss after lamivudine treatment for chronic hepatitis B. Hepatology 2002; 36: 186-94.

24. Liaw YF, Leung NW, Chang TT, Guan R, Tai DI, Ng KY, Chien RN, Dent J, Roman L, Edmundson S, Lai CL. Effects of extended lamivudine therapy in Asian patients with chronic hepatitis B. Asia Hepatitis Lamivudine Study Group. Gastroenterology 2000; 119: 172-80.

25. Leung NW, Lai CL, Chang TT, Guan R, Lee CM, Ng KY, Lim SG, Wu PC, Dent JC, Edmundson S, Condreay LD, Chien RN; On behalf of the Asia Hepatitis Lamivudine Study Group. Extended lamivudine treatment in patients with chronic hepatitis $B$ enhances hepatitis $B e$ antigen seroconversion rates: results after 3 yr of therapy. Hepatology 2001; 33: 1527-32.

26. Allen MI, Deslauriers M, Andrews CW, Tipples GA, Walters KA, Tyrrell DL, Brown N, Condreay LD. Identification and characterization of mutations in hepatitis B virus resistant to lamivudine. Lamivudine Clinical Investigation Group. Hepatology 1998; 27: 1670-7.

27. Dienstag JL, Goldin RD, Heathcote EJ, Hann HW, Woessner M, Stephenson SL, Gardner S, Gray DF, Schiff ER. Histological outcome during long-term lamivudine therapy. Gastroenterology 2003; 124: 105-17.

28. Liaw YF, Chien RN, Yeh CT, Tsai SL, Chu CM. Acute exacerbation and hepatitis $B$ virus clearance after emergence of YMDD motif mutation during lamivudine therapy. Hepatology 1999; 30: 567-72.

29. Ono-Nita SK, Kato N, Shiratori Y, Masaki T, Lan KH, Carrilho FJ, Omata M. YMDD motif in hepatitis B virus DNA polymerase influences on replication and lamivudine resistance: A study by in vitro full-length viral DNA transfection. Hepatology 1999; 29: 939-45.

30. Liaw YF, Chien RN, Yeh CT. No benefit to continue lamivudine therapy after emergence of YMDD mutations. Antivir Ther 2004; 9 : 257-62.

31. Wong VW, Chan HL, Wong ML, Tam JS, Leung NW. Clinical course after stopping lamivudine in chronic hepatitis B patients with lamivudine-resistant mutants. Aliment Pharmacol Ther 2004; 19: 323-9.

32. Dienstag JL, Cianciara J, Karayalcin S, Kowdley KV, Willems B, Plisek S, Woessner M, Gardner S, Schiff E. Durability of serologic response after lamivudine treatment of chronic hepatitis $B$. Hepatology 2003; 37: 748-55.

33. Song BC, Suh DJ, Lee HC, Chung YH, Lee YS. Hepatitis B e antigen seroconversion after lamivudine therapy is not durable in patients with chronic hepatitis B in Korea. Hepatology 2000; 32: 803-6.

34. Lee KM, Cho SW, Kim SW, Kim HJ, Hahm KB, Kim JH. Effect of virological response on post-treatment durability of lamivudine-induced HBeAg seroconversion. J Viral Hepat 2002; 9: 208-12.

35. Ryu SH, Chung YH, Choi MH, Kim JA, Shin JW, Jang MK, Park 
NH, Lee HC, Lee YS, Suh DJ. Long-term additional lamivudine therapy enhances durability of lamivudine-induced HBeAg loss: a prospective study. J Hepatol 2003; 39: 614-9.

36. Lee HC, Suh DJ, Ryu SH, Kim H, Shin JW, Lim YS, Chung YH, Lee YS. Quantitative polymerase chain reaction assay for serum hepatitis $B$ virus DNA as a predictive factor for post-treatment relapse after lamivudine induced hepatitis $B$ e antigen loss or seroconversion. Gut 2003; 52: 1779-83.

37. Marcellin P, Chang TT, Lim SG, Tong MJ, Sievert W, Shiffman ML, Jeffers L, Goodman Z, Wulfsohn MS, Xiong S, Fry J, Brosgart CL; Adefovir Dipivoxil 437 Study Group. Adefovir dipivoxil for the treatment of hepatitis B e antigen-positive chronic hepatitis B. N Engl J Med 2003; 348: 808-16.

38. Hadziyannis SJ, Tassopoulos NC, Heathcote EJ, Chang TT, Kitis G, Rizzetto M, Marcellin P, Lim SG, Goodman Z, Wulfsohn MS, Xiong S, Fry J, Brosgart CL; Adefovir Dipivoxil 438 Study Group. Adefovir dipivoxil for the treatment of hepatitis $B$ e antigen-negative chronic hepatitis B. N Engl J Med 2003; 348: 800-7.

39. Peters MG, Hann H-W, Martin P, Heathcote EJ, Buggisch P, Rubin R, Bourliere M, Kowdley K, Trepo C, Gray DF, Sullivan M, Kleber
K ER, Xiong S, Brosgart CL. Adefovir dipivoxil alone or in combination with lamivudine in patients with lamivudine-resistant chronic hepatitis B. Gastroenterology 2004; 126: 91-101.

40. Perrillo R, Hann H-W, Mutimer D, Willems B, Leung N, Lee WM, Moorat A, Gardner S, Woessner M, Bourne E, Brosgart CL, Schiff E. Adefovir dipivoxil added to ongoing lamivudine in chronic hepatitis B with YMDD mutant hepatitis B virus. Gastroenterology 2004; 126: 81-90.

41. Choi WB, Suh DJ, Kim SH, Lim YS, Lee HC, Chung YH, Lee YS. Adefovir dipivoxil alone or in combination with lamivudine in patients with lamivudine resistant decompensated liver disease. (abstract). Korean J Hepatol 2004; 10: S103.

42. Angus P, Vaughan R, Xiong S, Yang H, Delaney W, Gibbs C, Brosgart C, Colledge D, Edwards R, Ayres A, Bartholomeusz A, Locarni$\mathrm{ni}$ S. Resistance to adefovir dipivoxil therapy associated with the selection of a novel mutation in the HBV polymerase. Gastroenterology 2003; 125: 292-7.

43. Tanji N, Tanji K, Kambham N, Markowitz GS, Bell A, D’Agati VD. Adefovir nephrotoxicity: possible role of mitochondrial DNA depletion. Hum Pathol 2001; 32: 734-40. 